\title{
Management of severe asthma in children
}

\author{
Prof Andrew Bush, MD and Sejal Saglani, MD \\ Imperial School of Medicine, National Heart and Lung Institute, Royal Brompton Hospital, \\ London, UK
}

\begin{abstract}
Children who are referred to specialist care with asthma that does not respond to treatment (problematic severe asthma) are a heterogeneous group, with substantial morbidity. The evidence base for management is sparse, and is mostly based on data from studies in children with mild and moderate asthma and on extrapolation of data from studies in adults with severe asthma. In many children with severe asthma, the diagnosis is wrong or adherence to treatment is poor. The first step is a detailed diagnostic assessment to exclude an alternative diagnosis ("not asthma at all"), followed by a multidisciplinary approach to exclude comorbidities ("asthma plus") and to assess whether the child has difficult asthma (improves when the basic management needs, such as adherence and inhaler technique, are corrected) or true, therapy-resistant asthma (still symptomatic even when the basic management needs are resolved). In particular, environmental causes of secondary steroid resistance should be identified. An individualised treatment plan should be devised depending on the clinical and pathophysiological characterisation. Licensed therapeutic approaches include high-dose inhaled steroids, the Symbicort maintenance and reliever (SMART) regimen (with budesonide and formoterol fumarate), and anti-IgE therapy. Unlicensed treatments include methotrexate, azathioprine, ciclosporin, and subcutaneous terbutaline infusions. Paediatric data are needed on cytokine-specific monoclonal antibody therapies and bronchial thermoplasty. However, despite the interest in innovative approaches, getting the basics right in children with apparently severe asthma will remain the foundation of management for the foreseeable future.
\end{abstract}

\section{Introduction}

Although the evidence base for the treatment of mild-to-moderate asthma in children is expanding, ${ }^{1,2}$ paediatric asthma beyond stage 3 of the British Thoracic Society (BTS) and Scottish Intercollegiate Guidelines Network (SIGN) guidelines ${ }^{3}$ has been the subject of few good-quality studies. Several reviews have been published ${ }^{4-6}$ but primary data are sparse. Reviews have emphasised the wide differential diagnosis in children, the need to involve the school, as well as the home ${ }^{4}$ the role of viral infections, ${ }^{5}$ and the importance of monitoring longitudinal change in lung function. ${ }^{6}$ Children with true therapy-resistant asthma constitute less than half of children referred with problematic severe asthma, and undergo detailed assessments of symptoms, spirometry, and inflammation, including invasive investigations such as bronchoscopy, before new therapies are used. This process helps to diagnose different forms of asthma: asthma, which is clinically characterised by poor control and multiple exacerbations, brittle asthma, with chaotic swings in peak flow, and severe asthma with fungal sensitisation, and persistent airflow limitation. Pathologically, asthma is

Correspondence to: Prof Andrew Bush, Department of Paediatric Respiratory, Medicine, Royal Brompton Hospital, Sydney Street, London, SW3 6NP, UK, a.bush@rbh.nthames.nhs.uk.

Contributors: $\mathrm{AB}$ wrote the initial draft of the paper. Both authors reviewed subsequent revisions and the final version of this Review.

Conflicts of interest: We declare that we have no conflicts of interest. 
characterised on the basis of proximal luminal inflammation, as persistently eosinophilic, neutrophilic, or paucicellular asthma. In this Review, we focus on children of school age and adolescents. We are not aware of any randomised controlled trials of treatment in true, therapy-resistant paediatric asthma, so we have based recommendations on personal practice, with cautious extrapolation from published papers on adult severe asthma and paediatric mild-to-moderate asthma. Many cases of apparently treatment-unresponsive asthma arise because the basics (eg, adherence, inhaler technique, dose and frequency, minimisation of allergen, and smoke exposure) have not been dealt with correctly. ${ }^{7-9}$ In a study in which two add-on regimens in symptomatic children were compared, despite being prescribed at least $400 \mu \mathrm{g}$ budesonide per day plus a long-acting $\beta 2$ agonist, only 55 of 292 children assessed for eligibility could be randomised; of the other 237 children, 89 were non-adherent and 59 had mild or no asthma. ${ }^{7}$ In two well designed negative trials ${ }^{8,9}$ in which the use of fractional exhaled nitric oxide (FeNO) was studied as an add-on to standard monitoring of uncontrolled asthma, similar problems occurred. In the first study, ${ }^{8}$ in the runin period when basic management was assessed, the improvements in both groups were so great that there was little, if any, scope for further improvement. In the second study, ${ }^{9}$ in which detailed FeNO telemonitoring was used to adjust treatment, with intensive three weekly telephone contacts in control and active groups, both groups had the same amount of improvement in symptoms and reduction in inhaled corticosteroids. Despite guideline-based therapy and measurement of inflammatory markers ("inflammometry"), leading to excellent baseline control, many children still had severe exacerbations that required oral steroid therapy. This failure to control exacerbations indicates the dissociation between control and exacerbations, and that the problem of exacerbations merits more attention, which we further discuss later.

Thus, for a child with apparently severe asthma, the first step is to confirm the diagnosis and ensure that basic management strategies are in place. These strategies should affirm that an appropriate drug delivery device is used, that adherence to treatment is good, and that exposure to environmental triggers is minimised. ${ }^{10}$

\section{Domains of severity in paediatric asthma}

The four suggested domains of severity are given in panel 1 . This classification assumes that acute exacerbations and baseline control, although overlapping, are distinct features, ${ }^{12,13}$ which we further discuss later. Referral to specialist care will usually be prompted by symptoms (either exacerbations or poor control, or both), concerns about safety of the amount of medication, and future risk after an admission to intensive care.

\section{Patterns of difficulty that trigger referral to specialist care}

The different problems that trigger referral were characterised in one study as either "chaotic" (more than 30\% variability in spirometry) or "non-chaotic" (less than 15\% variability). ${ }^{14}$ These characteristics can be broken down into one or more of the categories provided in panel 2 , listed in no particular order. These categories are unrefined, and novel biomarkers and mathematical analyses ${ }^{19,20}$ will hopefully soon enable us to improve on clinical categorisation. We use these groupings because treatment will probably differ between them; for example, children with persistent airflow limitation might be able to have treatment reduced, unlike in the other categories.

\section{The entry label: "problematic severe asthma"}

When the child is initially referred, it will not be clear whether (1) the diagnosis is wrong ("not asthma at all"), and a diagnostic re-evaluation (not discussed in this Review) is essential; (2) the asthma is mild, but exacerbated by one or more comorbidities ("asthma 
plus"); (3) whether this is "difficult-to-treat asthma" because of potentially reversible factors such as poor adherence to treatment or poor inhalation technique; or (4) they have true "severe, therapy-resistant asthma", which remains refractory to treatment even when reversible factors have been taken into account. There can be overlap between the second and third group. We use the general term "problematic severe asthma" to encompass these four categories. ${ }^{21}$ Children with this type of asthma have a different and less diverse presentation than do adults. ${ }^{22}$ They use health-care services more often, despite the prescription of at least two controller therapies, they have a high morbidity, including exacerbations, admissions to intensive care, and prednisolone use, most are atopic with multiple sensitisations, and, unlike in adults, there is a male preponderance..$^{22-24}$

\section{The first step: is it likely to be true severe, therapy-resistant asthma?}

As a first step, we recommend a detailed re-evaluation, including both a hospital-based session and a nurse-led home visit. ${ }^{25}$ The current evidence base for the benefit of many measurements is poor, and much work is aimed at prospectively generating research data.

\section{The hospital visit}

We use a detailed checklist on symptom patterns and psychosocial factors. Because there is an imperfect concordance between skin prick tests and radio-allergosorbent tests (76$83 \%),{ }^{26-29}$ allergic sensitisation to aeroallergens (grass and tree pollen, house dust mite, cockroach, cat, dog), fungi (Aspergillus fumigatus, Alternaria alternata, Cladosporium herbarum, Penicillium chrysogenum, Candida albicans, Trichophyton mentagrophytes, Botrytis cinerea ${ }^{26}$ ), and food allergens (peanut, milk, egg), as well as any others clinically indicated, is assessed by both tests. We measure FeNO, spirometry, and bronchodilator response, and, if $\mathrm{FEV}_{1}$ is more than $70 \%$ predicted, induced sputum cell counts. Saliva is collected for cotinine concentrations as an objective measure of exposure to tobacco smoke. If prednisolone or theophylline have been prescribed, blood concentrations of the drugs are measured. An appointment is made for the specialist respiratory nurse to visit the home.

The role of spirometry, bronchodilator responsiveness, and bronchial challenge testing-Unlike in adults, use of spirometry is poorly discriminatory between asthma of different severities in children. ${ }^{30-32}$ Use of spirometry is helpful as part of the definition of an exacerbation and for monitoring progression of lung growth over time. ${ }^{6,14}$ Epidemiological evidence is that, for groups, spirometry data in severe asthma can be tracked over decades. ${ }^{33,34}$ For individuals, there is evidence that, despite apparently good control of symptoms with inhaled corticosteroids, lung function can deteriorate over time. ${ }^{6,14,35}$ In a post-hoc analysis, this deterioration was associated with the exacerbating phenotype, but only in patients not treated with inhaled corticosteroids. ${ }^{36}$ This study requires prospective confirmation. Bronchodilator responsiveness might be used as part of the diagnostic process and to define persistent airflow limitation (as mentioned earlier). There are few studies on the role of bronchial challenge testing as a clinical tool in problematic severe asthma. In many children, this testing is too risky because of poor lung function and extreme bronchial hyper-reactivity. Bronchial challenge testing might have a role in the diagnostic assessment; in a child with normal spirometry and reported severe symptoms, a negative challenge would make uncontrolled asthma unlikely. The role of this testing in children with persistent airflow limitation or obliterative bronchiolitis, as part of confirmation that further escalation of therapy is not useful, is not clear.

The role of high-resolution CT scanning-High-resolution CT scanning (HRCT) might be done as part of the diagnostic assessment, if, for example, the patient is non-atopic or if bronchiectasis is suspected. However, in adult studies, bronchial wall dilatation is 
common in severe asthma, ${ }^{37,38}$ and it is important not to over-diagnose bronchiectasis.

HRCT scans might not help to distinguish severe asthma from obliterative bronchiolitis. ${ }^{39}$ In adults, there is evidence that HRCT scans might be a useful biomarker of asthma severity ${ }^{40,41}$ but the evidence is much less clear in children. In children, HRCT changes consistent with asthma are less apparent than those in adults, ${ }^{42}$ and bronchial wall thickening has no or only weak correlation with thickening of the reticular basement membrane and decreases in $\mathrm{FEV}_{1} \cdot{ }^{43-46}$ Air trapping on HRCT might enable an estimate of distal airway disease, ${ }^{47,48}$ but has not been compared in severe asthma with sophisticated tests of distal airway function such as lung clearance index. ${ }^{49,50} \mathrm{We}$ are not aware of any studies on the usefulness of HRCT scans as a longitudinal tool to monitor severe paediatric asthma, and the radiation risk of even low-dose HRCT in young children should be carefully considered. In summary, there is no evidence to recommend routine HRCT as a clinical test in true severe, therapy-resistant paediatric asthma.

\section{The home visit}

We have recently reported the use of home visits as part of the assessment of problematic severe asthma. ${ }^{25}$ Here, we discuss four areas that are assessed in home visits: adherence to treatment, exposure to tobacco smoke, allergens, and psychosocial factors. Asthma education is also an important part of this process. ${ }^{51}$ This approach might not be feasible in all cases, but in our experience, it enables the identification of important and potentially reversible factors in more than half of patients referred with problematic severe asthma.

Adherence to treatment-Most information comes from paediatric community-based studies and adults with severe asthma, rather than in children with severe asthma. ${ }^{52-55} \mathrm{In}$ summary, adherence to treatment is often poor, and parents overestimate how much drug is being given. In our series of home visits of 71 patients, ${ }^{25}$ less than half the patients had picked up more than $80 \%$ of the required prescriptions, and nearly a third had picked up less than $50 \%$, similar to that reported in previous work. ${ }^{56}$ Drugs were often past the expiry date. Even young children (20\% of 7-year-olds and $50 \%$ of 11-year-olds) were left to take asthma treatments unsupervised. ${ }^{57}$ Competence with inhaler devices was often poor, and although regular sessions with a respiratory nurse might improve this, ${ }^{58-60}$ all the children in our series had received repeated instruction in a specialised centre, and yet still had a poor technique. A key message is that even multiple teaching sessions are not enough to ensure good inhaler techniques. In our series, treatment-related issues (such as inappropriate use of drug delivery devices, non-adherence to treatment regimens, and out-of-date drugs), contributed to poor control in about half the patients. Another important use of prescription records is to identify which patients collect excessive prescriptions of short-acting $\beta 2$ agonists; collecting six or more per year was associated with a poor outcome in a community-based study. ${ }^{53}$

Environmental tobacco smoke-Data from many studies suggest that active smoking by adults with asthma leads to steroid resistance, ${ }^{61-64}$ and exposure to passive smoke probably has the same effect. Symptoms are also likely to be exacerbated by a direct irritant effect. Exposure to passive smoke is common in asthmatic children; ${ }^{65-67}$ the frequency of active smoking is unknown. In our series of home visits, ${ }^{25} 25 \%$ of children with problematic severe asthma were exposed to tobacco smoke. The mechanisms of tobacco smoke-induced steroid resistance have been researched mainly in adults. ${ }^{68}$

Ongoing allergen exposure-Allergen exposure, at a level insufficient to cause acute deterioration, leads to increased airway inflammation, bronchial responsiveness, ${ }^{69}$ and steroid resistance via interleukin-2-dependent and interleukin 4-dependent mechanisms ${ }^{70,71}$ in adults. High allergen exposure in the home and allergic sensitisation is a cause of acute 
exacerbations of asthma in children. ${ }^{72}$ Allergen exposure in schools might also be important, ${ }^{73}$ but this possibility is an even more difficult area in which to intervene. Lowdose exposure to cat allergen on the clothes of classmates at school is sufficient to cause deterioration of asthma. ${ }^{73}$ The aeroallergens likely susceptible to intervention are pets, cockroaches, moulds, and house dust mites. House dust mites are a controversial area because, although there is little evidence for routine use of avoidance measures for most children sensitised to these aeroallergens, no study has convincingly evaluated whether there will be benefit in children with severe asthma, the group that might be most likely to comply with the demanding regimens needed. ${ }^{74-76}$

People with asthma of all levels of severity are commonly exposed to allergens in the home. ${ }^{65-67}$ Pet and cockroach sensitisation might be a marker for high morbidity, ${ }^{77,78}$ although whether cockroach sensitisation can be separated from the effects of low socioeconomic status is arguable. ${ }^{66} \mathrm{An}$ interaction between passive smoking and pet sensitisation might exist. ${ }^{79}$ The use of synthetic bedding might be associated with severe wheeze. ${ }^{80}$ In our study of home visits, ${ }^{25} 30$ children owned furry pets, 17 of whom were sensitised on skin prick testing, and only two implemented any allergen avoidance precautions. 31 children had clinically significant exposure to house dust mites; five were taking comprehensive allergen avoidance measures, 15 were implementing partial measures, and 11 were adopting no measures. The association between allergen exposure, allergen sensitisation, and symptoms are complex and can vary from antigen to antigen. ${ }^{81} \mathrm{An}$ allergen can lead to symptoms even without evidence of specific IgE-mediated sensitisation. ${ }^{82,83}$ Nonetheless, in a child with severe symptoms of asthma, attempts to reduce environmental allergen exposure seems reasonable (we review such evidence later).

Psychosocial factors-The importance of acute and chronic stress as a trigger of asthma exacerbations is well recognised. ${ }^{84-86}$ Stress amplifies the airway eosinophilic response to an allergen challenge. ${ }^{87}$ In our study, ${ }^{25}$ these triggers were common, particularly anxiety and depression, and most were only identified during discussions in the home. About half were referred to clinical psychology. Assessment of whether anxiety and depression are the cause or result of severe asthma is not productive; both are treated appropriately.

\section{Comorbidities}

In this section, we briefly outline some of the comorbidities associated with paediatric asthma.

Gastro-oesophageal reflux-The evidence that reflux causes asthma, and that treatment of reflux improves asthma, is of poor quality, with few adequately designed studies and small cohorts. ${ }^{88,89}$ In our experience, treatment of apparently asymptomatic reflux in children with severe asthma is seldom helpful. However, we still deem it appropriate to exclude reflux as a comorbidity as part of our assessment because, on rare occasions, patients might improve on anti-reflux therapy (as discussed later).

Rhinosinusitis-Upper airway disease worsens quality of life and should be treated appropriately in any context. ${ }^{90-92}$ Treatment of concomitant rhinosinusitis alleviates severe asthma in adults but whether similar treatment is effective in children is not clear.

Dysfunctional breathing-Vocal cord dysfunction and other forms of dysfunctional breathing are common in patients with asthma, and the symptoms are frequently wrongly attributed to asthma. This comorbidity is much less well studied in adults than in children. ${ }^{93-95}$ In our series, ${ }^{25} 15 \%$ (11 of 71) had evidence of dysfunctional breathing, including hyper ventilation and vocal cord dysfunction. 
Dyspnoea perception has been little studied in severe paediatric asthma, ${ }^{96}$ but in adults with severe asthma, patients do not become as dyspnoeic as those with mild asthma during bronchoconstriction. ${ }^{97}$

Obesity-The interactions between obesity and asthma are complex. Obesity might cause diagnostic confusion (breathlessness without evidence of asthma), a pauci-inflammatory form of asthma, ${ }^{19}$ and steroid resistance. ${ }^{98}$ Asthma and its treatment might contribute to obesity (oral steroid bursts, immobility). For these reasons, particular care is necessary in the management of children who are obese with respiratory symptoms. Weight reduction is always beneficial, but is difficult to achieve.

Food allergy-Asthmatics with a food allergy are over-represented in cohorts of children with severe asthma. ${ }^{99,100}$ Whether food allergy is causative or shares a common pathway is unclear. It would seem sensible to err on the side of over-treatment of a child with asthma who has a documented food allergy.

\section{Multidisciplinary team discussion}

Our recommended next step is discussion of the assessment by the multidisciplinary team. The aim is to decide whether further invasive investigations are justified and, if not, to develop a plan to address the reversible factors identified. In 55\% of children (39 of 71), ${ }^{25}$ no further investigations were undertaken. Unfortunately, this percentage does not mean that the problem is necessarily solved; identification of poor adherence as a problem is different to resolving the problem itself. There is also evidence that interventions within the caregiver-patient relationship, which are costly in time and resources, might improve adherence. ${ }^{56}$ Data from large community studies (but not in patients with severe asthma) suggest that this sort of individualised, multifaceted environmental intervention is beneficial and cost effective, ${ }^{101-103}$ with benefits continuing for at least 1 year after the intervention has ceased. The more drastic step of taking children with asthma out of their environment altogether was unsuccessful in only five of 60 children. ${ }^{67}$ Psychological interventions might be effective, ${ }^{104}$ although, in general, individualised plans work best. ${ }^{101,105,106}$

Our data have important implications for the interpretation of other studies. Cohorts of children with severe asthma who have not gone through a detailed filtering process will include at least $50 \%$ of children in whom the basic management needs have not been addressed, and results from these individuals might not be comparable to those with truly therapy-resistant asthma.

\section{The next steps: invasive investigation?}

Once the clinician is satisfied that the basic management needs are right, there is even less evidence to help decide on the next steps. Our personal practice is to use a two-stage, invasive protocol. The aims of this protocol are to identify the following. (1) Whether there is an additional unsuspected diagnosis. (2) Whether there is discordance between symptoms and airway inflammation, particularly if the child is symptomatic with no evidence of inflammation. Giving patients increasingly potent anti-inflammatory drugs seems illogical if there is no residual inflammation left to treat. (3) The response to a single dose of intramuscular depot triamcinolone to assess whether there is at least partial steroid-resistant airway inflammation. (4) Whether there is evidence of non-eosinophilic, particularly neutrophilic inflammation.

We re-assess symptoms and the use of rescue treatment, FeNO, spirometry and bronchodilator response, and (if considered safe) induced sputum cytology. After the child undergoes fibreoptic bronchoscopy under general anaesthesia, bronchoalveolar lavage, and 
endobronchial biopsy, a pH probe is done, and intramuscular triamcinolone $80 \mathrm{mg}$ is given. In the second stage, 3-4 weeks later, we repeat all the above non-invasive measurements, although a second bronchoscopy is not done. Finally, we develop an individualised treatment plan.

\section{Steroid responsiveness}

There is no accepted definition of steroid resistance in children, and the mechanisms are unclear. Congenital steroid resistance from mutations in the corticosteroid receptor is rare. ${ }^{107}$ Acquired steroid resistance can extend over a range and can be overcome by high doses, albeit at the risk of increased side-effects. There are many potential mechanisms of steroid resistance, ${ }^{108,109}$ but these have been studied mostly in adults and the relevance in children is not clear. What is clear is that, despite high-dose inhaled and oral steroid therapy, children might have continuing symptoms and airway reactivity, even in the absence of proximal inflammation. ${ }^{110,111}$ The adult definition of steroid resistance $(<15 \%$ increase in $\mathrm{FEV}_{1}$ after 2 weeks of oral prednisolone in a patient who can bronchodilate more than $15 \%$ with acute use of $\beta 2$ agonists) ${ }^{112}$ is not appropriate for children, who can have normal spirometry despite severe asthma. ${ }^{30-32}$ Possible criteria are given in table 1 . We also do not know the correct dose and duration of the steroid trial. For example, a 2-week course of prednisolone is not necessarily predictive of best lung function in children with asthma. ${ }^{116}$ We use parenteral steroids to ensure that adherence is complete.

\section{Treatment of severe, therapy-resistant asthma}

Unfortunately, treatment of severe, therapy-resistant asthma relies on a series of individual trials of single patients. In our clinical practice, we initially use drugs licensed in children before trying unlicensed and experimental therapy. Treatment strategies are summarised in tables 2 and 3, and some aspects are discussed in more detail later. This section reflects personal practice, not an evidence-based approach.

\section{Treatment of eosinophilic inflammation}

In our experience, the most common inflammatory pattern is eosinophilic inflammation, and this response persists after a single dose of triamcinolone in $50 \%$ of children. ${ }^{117}$ Options for treatment include: (1) high-dose inhaled corticosteroid; in severe asthma, the plateau of the dose-response curve might be increased; ${ }^{118}$ (2) the SMART regimen (combined budesonide and formoterol turbohaler as the only treatment), which might reduce exacerbations in particular; ${ }^{119-121}$ and (3) further doses of triamcinolone. ${ }^{122}$

For children with persistent asthma, IgE-mediated sensitisation, and eosinophilic inflammation, despite tolerable levels of treatment and for whom every reasonable effort has been made to reduce the burden of allergen exposure, we next trial omalizumab. ${ }^{123-125}$ In many children, the IgE blood levels are higher than recommended for this therapy. ${ }^{24} \mathrm{We}$ have still tried omalizumab in these children, but the likelihood of success is much lower if $\mathrm{IgE}$ levels are high. For children who do not respond to treatment, and continue to require high-dose systemic steroids, the only other option is steroid-sparing drugs such as methotrexate, azathioprine, or ciclosporin. ${ }^{126-128}$ Evidence of efficacy is confined to case series.

\section{Treatment of the exacerbating phenotype}

Acute asthma exacerbations cause substantial morbidity, sometimes death, and are an independent risk factor for an accelerated decline in lung function. ${ }^{36}$ These exacerbations cannot be abolished completely. Exacerbation and baseline control are not the same thing; loss of baseline control is characterised by wide diurnal peak expiratory flow variation, 
whereas acute exacerbation is indicated by a steep decline in peak flow, with no increased variability. ${ }^{13,14}$ Factors associated with exacerbations include extrinsic features, such as treatment non-compliance and psychosocial morbidities, and intrinsic factors such as poor production of interferons. ${ }^{129-131}$ Children might have good control, but can still have exacerbations, ${ }^{132}$ and increasing interval treatment only increases the risk of side-effects. However, poor control ${ }^{133}$ and previous severe exacerbations ${ }^{134,135}$ are both predictive of future acute exacerbations.

The exacerbating phenotype can cover a range of severities. In pre-school children who only wheeze with viral colds there is no evidence that allergens have any role. In older children, the combination of respiratory viral infection and both sensitisation and exposure in the home to high concentrations of allergens is strongly predictive of exacerbations in those with asthma. ${ }^{72}$ These exacerbations are typically characterised by mixed eosinophilic and neutrophilic inflammation, or pure neutrophilic inflammation. ${ }^{136-138}$ However, high-dose allergen exposure can cause acute exacerbations (eg, thunderstorm asthma ${ }^{139}$ and the soya bean asthma epidemic in Barcelona ${ }^{140}$ ), which are characterised by sputum eosinophilia. ${ }^{141}$ Data from studies in adults suggest that the exacerbating phenotype could be characterised by persistent sputum eosinophilia between exacerbations, and might respond to antiinterleukin-5 antibody. ${ }^{142,143}$

In school-age children with multiple exacerbations, we aim to increase the baseline dose of inhaled corticosteroid to abolish interval sputum eosinophilia. However, high-dose inhaled corticosteroids do not affect the severity of exacerbations. Long-acting $\beta 2$ agonists also reduce numbers of exacerbation. ${ }^{119-121}$ Once allergen sensitisation is identified, avoidance measures can be advised. High-dose inhaled corticosteroids ${ }^{144}$ or leukotriene receptor antagonists $^{145}$ can be considered at the first sign of a viral exacerbation. However, none of these measures will completely obviate the need for oral corticosteroids. Finally, if exacerbations are of sudden onset, with rapid deterioration over minutes, we provide the child with a source of injectable epinephrine (by use of an auto-injector). The hospital treatment of acute exacerbations is beyond the scope of this Review. ${ }^{3}$

\section{Other treatment strategies}

Many of the other treatment strategies include unlicensed and potentially dangerous therapies, and must be thoroughly discussed with the child and family, with the risks and benefits carefully taken into account.

For type 1 brittle asthma, the options are high-dose formoterol, often using a variant of the SMART regimen, or continuous subcutaneous infusion of terbutaline. ${ }^{146}$ In either case, the risks of high-dose $\beta 2$ agonists should be discussed. ${ }^{147,148}$ If continuous subcutaneous terbutaline is used, we recommend that a double-blind trial is done in hospital; the child and family know that only the ward pharmacist will know which is the active treatment period. Commonly, when the child is in hospital, receiving drugs under supervision and away from an adverse environment, asthma improves irrespective of subcutaneous therapy.

Persistent airflow limitation might be caused by genuine asthma, but is also commonly caused by obliterative bronchiolitis. Often, treatment has been escalated with no response. Treatment is reduced until there is evidence of airway inflammation and bronchodilator reversibility.

Paucicellular asthma is common; only nine of 28 symptomatic children had evidence of cellular inflammation on induced sputum. ${ }^{149}$ Reduction of steroid therapy is recommended. 
For neutrophilic asthma, we use oral theophyllines, which accelerate neutrophil apoptosis, ${ }^{150}$ and macrolides. Macrolides have proven value in other neutrophilic airway diseases, ${ }^{151-156}$ and there is some evidence of benefit in adult neutrophilic asthma. ${ }^{157,158}$ Finally, because corticosteroids inhibit neutrophil apoptosis, ${ }^{159}$ a cautious steroid taper might be worth considering. These options are only recommended for experienced specialists.

Severe asthma with fungal sensitisation is defined as severe asthma with evidence of sensitisation to one or more of seven fungi (as specified earlier). ${ }^{26}$ Allergic bronchopulmonary aspergillosis is rare in paediatric asthma, but fungal sensitisation is common. Fungal sensitisation can be associated with severe morbidity, ${ }^{160-162}$ and there should be a low threshold for scaling up therapy in affected children. In a randomised trial in adults with severe asthma with fungal sensitisation, benefit for itraconazole was reported. ${ }^{26}$ Data in children are sparse, ${ }^{163}$ but for those who meet adult criteria for severe asthma with fungal sensitisation fungal exposure should probably be minimised and a trial of itraconazole or even voriconazole should be considered (although the risk of Cushing's syndrome with inhaled corticosteroids and itraconazole should be kept in mind ${ }^{164}$ ).

\section{Future treatment options}

Future treatment options include therapies trialled in adults, and consideration of specific paediatric factors.

Anti-interleukin-5 antibody, other monoclonal anti-bodies, and bronchial thermoplasty all show promise in adults ${ }^{141,142,165,166}$ but there are no data in children. The value of carefully characterising patients rather than treating anyone with severe asthma is evident in adult studies of anti-interleukin-5; ${ }^{141,142}$ it is likely that this same careful approach will be needed for treatment of children.

The mechanisms of failure of normal airway growth, and subsequent accelerated decline in lung function, are unclear but probably involve airway remodelling. Current problems in treating airway remodelling include the absence of any biomarker, the difficulty in distinguishing changes that might actually be beneficial (reticular basement membrane thickening might be protective ${ }^{167}$ ), and the scarcity of any therapeutic interventions. Macrolides might possibly be used in the future. ${ }^{168}$ Although a recent study ${ }^{7}$ showed no benefit for add-on therapy with azithromycin, the number of participants was small and, although the authors concluded that a larger study would have revealed no benefit, ruling out the use of macrolides in every severe asthma phenotype on the basis of a single small trial would be premature.

\section{Monitoring therapy}

The use of home physiological monitoring and written treatment plans seems advisable, but there is little evidence for benefit in severe asthma. ${ }^{51,169}$ If perception of symptoms is poor, an objective measurement should be useful, but whether peak flow meters are sufficiently accurate, or likely to be used, is unknown. It is likely, but completely unproven, that compliance would be better in patients with severe rather than moderate asthma. We use home monitoring in these children, although with a poor evidence base.

Use of inflammatory markers to monitor severe asthma would probably be beneficial. In studies in patients with mild-to-moderate asthma, in whom it is less likely that the use of inflammatory markers will give added value, measurements of FeNO, bronchial responsiveness, and sputum eosinophils have been suggested to be useful to titrate therapy with inhaled corticosteroids, predict exacerbations, enable successful inhaled steroid 
reduction, and predict relapse after stopping inhaled corticosteroids. ${ }^{170-172}$ However, in a randomised controlled trial of 55 children with severe asthma in which monitoring sputum eosinophils (or if sputum could not be produced, FeNO) was compared with a standard strategy, there were only non-significant trends for benefit. ${ }^{173}$ Reasons for this nonsignificance included unexpected phenotypic variability 174 and the inconstant association between FeNO and sputum eosinophils in this group. ${ }^{175}$ In adults, the eosinophilic and noneosinophilic phenotypes seem stable. ${ }^{176}$ By contrast, $39 \%$ of children (17 of 44) had at least one switch in phenotype over 1 year. ${ }^{174}$ Although FeNO and sputum eosinophilia was used interchangeably in a study of adults with mild asthma, ${ }^{177}$ in children with severe asthma the association between the two biomarkers varied over time even in the same individual. ${ }^{176}$ There might be discordance (a high FeNO with normal sputum eosinophils, or a normal FeNO with high eosinophils) or concordance (both high or both normal), and all four combinations can be seen in the same individual. Because sputum induction is not possible in at least $20 \%$ of children, better biomarkers of airway eosinophilia than FeNO are needed. ${ }^{177}$

\section{Future perspectives}

Current strategies mainly use sputum to monitor proximal airway luminal inflammation. However, other compartments might be important and discordant. In bronchoscopic studies in children, airway mucosal and luminal changes can be different, ${ }^{178}$ and it is unclear which is most important. We have no non-invasive biomarkers for mucosal inflammation. Distal airway inflammation may cause poorly controlled or nocturnal asthma. ${ }^{179-181}$ In a study in adults, nocturnal asthma was associated with an increase in inflammatory cells in a transbronchial biopsy sample, but not in an endobronchial biopsy sample. ${ }^{181}$

The only potential biomarker of distal airway inflammation in children is FeNO partitioned into proximal $\left(\mathrm{J}_{\mathrm{NO}}\right)$ and distal $\left(\mathrm{C}_{\mathrm{ALV}}\right)$ airways. ${ }^{182,183}$ This limitation to this biomarker has several practical problems. First, nearly $20 \%$ of children cannot produce results that fit the linear model. ${ }^{184}$ Second, the association between nitric oxide and eosinophilic inflammation is weak (as mentioned earlier). ${ }^{175}$ Finally, although $\mathrm{C}_{\mathrm{ALV}}$ can be used to show differences between groups, ${ }^{185}$ there is such a degree of overlap that it is unlikely to be able to guide the use of treatment in an individual. Thus, we need information about the importance of proximal and distal tissue inflammation, and distal luminal inflammation, with regard to proximal luminal inflammation. Furthermore, we need information on non-invasive biomarkers that is robust enough to be of value in monitoring individuals. Biomarkers are needed to guide management, specifically to quickly identify children who are not doing well, and to identify responders (and, more importantly, non-responders) to innovative and potentially dangerous therapies.

Despite the interest in mechanisms, biomarkers, phenotypes, and novel treatment strategies for patients with severe, therapy-resistant asthma, the current best approach is thorough multidisciplinary assessment of children with problematic severe asthma, which should result in at least half of these children being successfully managed with conventional treatments. ${ }^{25}$

\section{References}

1. Sorkness CA, Lemanske RF Jr, Mauger DT, et al. Childhood Asthma Research and Education Network of the National Heart, Lung, and Blood Institute. Long-term comparison of 3 controller regimens for mild-moderate persistent childhood asthma: the Pediatric Asthma Controller Trial. J Allergy Clin Immunol. 2007; 119:64-72. [PubMed: 17140647]

2. Lemanske RF Jr, Mauger DT, Sorkness CA, et al. Childhood Asthma Research and Education (CARE) Network of the National Heart, Lung, and Blood Institute. Step-up therapy for children 
with uncontrolled asthma receiving inhaled corticosteroids. N Engl J Med. 2010; 362:975-85. [PubMed: 20197425]

3. British Thoracic Society. Scottish Intercollegiate Guidelines Network. British Guideline on the management of asthma. Thorax. 2008; 63(suppl 4):iv1-121. [PubMed: 18463203]

4. Wenzel S, Szefler SJ. Managing severe asthma. J Allergy Clin Immunol. 2006; 117:508-01. [PubMed: 16522447]

5. Gern JE. Effects of viral respiratory infections on lung development and childhood asthma. J Allergy Clin Immunol. 2005; 115:668-74. [PubMed: 15805982]

6. Szefler SJ. Facing the challenges of childhood asthma: what changes are necessary? J Allergy Clin Immunol. 2005; 115:685-88. [PubMed: 15805985]

7. Strunk RC, Bacharier LB, Phillips BR, et al. Azithromycin or montelukast as inhaled corticosteroidsparing agents in moderate-to-severe childhood asthma study. J Allergy Clin Immunol. 2008; 122:1138-44. [PubMed: 18951618]

8. Szefler SJ, Mitchell H, Sorkness CA, et al. Management of asthma based on exhaled nitric oxide in addition to guideline-based treatment for inner-city adolescents and young adults: a randomised controlled trial. Lancet. 2008; 372:1065-72. [PubMed: 18805335]

9. de Jongste JC, Carraro S, Hop WC, CHARISM Study Group. Baraldi E. Daily telemonitoring of exhaled nitric oxide and symptoms in the treatment of childhood asthma. Am J Respir Crit Care Med. 2009; 179:93-97. [PubMed: 18931330]

10. Brand PLP, Ratjen F, Aurora P, et al. Paediatrics in Vienna. Eur Respir J. 2010; 35:1172-78. [PubMed: 20075043]

11. Brand PL, Baraldi E, Bisgaard H, et al. Definition, assessment and treatment of wheezing disorders in preschool children: an evidence-based approach. Eur Respir J. 2008; 32:1096-110. [PubMed: 18827155]

12. Reddel HK, Taylor DR, Bateman ED, et al. American Thoracic Society/European Respiratory Society Task Force on Asthma Control and Exacerbations. An official American Thoracic Society/ European Respiratory Society statement: asthma control and exacerbations: standardizing endpoints for clinical asthma trials and clinical practice. Am J Respir Crit Care Med. 2009; 180:59-99. [PubMed: 19535666]

13. Reddel H, Ware S, Marks G, Salome C, Jenkins C, Woolcock A. Differences between asthma exacerbations and poor asthma control. Lancet. 1999; 353:364-69. [PubMed: 9950442]

14. Chan MTS, Leung DYM, Szefler SJ, Spahn JD. Difficult-to-control asthma: clinical characteristics of steroid-insensitive asthma. J Allergy Clin Immunol. 1998; 101:594-601. [PubMed: 9600494]

15. Adams NP, Bestall JC, Jones P, Lasserson TJ, Griffiths B, Cates CJ. Fluticasone at different doses for chronic asthma in adults and children. Cochrane Database Syst Rev. 2008; 4:CD003534. [PubMed: 18843646]

16. Brouwer AF, Brand PL, Roorda RJ, Duiverman EJ. Airway obstruction at time of symptoms prompting use of reliever therapy in children with asthma. Acta Paediatr. 2010; 99:871-76. [PubMed: 20151953]

17. Ayres JG, Miles JF, Barnes PJ. Brittle asthma. Thorax. 1998; 53:315-21. [PubMed: 9741378]

18. Stanojevic S, Wade A, Stocks J, et al. Reference ranges for spirometry across all ages: a new approach. Am J Respir Crit Care Med. 2008; 177:253-60. [PubMed: 18006882]

19. Haldar P, Pavord ID, Shaw DE, et al. Cluster analysis and clinical asthma phenotypes. Am J Respir Crit Care Med. 2008; 178:218-24. [PubMed: 18480428]

20. Moore WC, Meyers DA, Wenzel SE, et al. Identification of asthma phenotypes using cluster analysis in the severe asthma program. Am J Respir Crit Care Med. 2010; 181:315-23. [PubMed: 19892860]

21. Bush A, Hedlin G, Carlsen KH, de Benedictis F, Lodrup-Carlsen K, Wilson N. Severe childhood asthma: a common international approach? Lancet. 2008; 372:1019-21. [PubMed: 18805316]

22. Fitzpatrick AM, Gaston BM, Erzurum SC, Teague WG. National Institutes of Health/National Heart, Lung and Blood Institute Severe Asthma Research Program. J Allergy Clin Immunol. 2006; 118:1218-25. [PubMed: 17157650] 
23. Chipps BE, Szefler SJ, Simons ER, et al. TENOR study group. Demographic and clinical characteristics of children and adolescents with severe or difficult-to-treat asthma. J Allergy Clin Immunol. 2007; 119:1156-63. [PubMed: 17397912]

24. Bossley CJ, Saglani S, Kavanagh C, et al. Corticosteroid responsiveness and clinical characteristics in childhood difficult asthma. Eur Respir J. 2009; 34:1052-59. [PubMed: 19541710]

25. Bracken M, Fleming L, Hall P, et al. The importance of nurse-led home visits in the assessment of children with problematic asthma. Arch Dis Child. 2009; 94:780-84. [PubMed: 19546102]

26. Denning DW, O'Driscoll BR, Powell G, et al. Randomized controlled trial of oral antifungal sensitization. The fungal asthma sensitization trial (FAST) study. Am J Respir Crit Care Med. 2009; 179:11-18. [PubMed: 18948425]

27. Wang J, Visness CM, Calatroni A, et al. Effect of environmental allergen sensitization on asthma morbidity in inner-city asthmatic children. Clin Exp Allergy. 2009; 39:1381-89. [PubMed: 19489919]

28. O'Driscoll BR, Powell G, Chew F, et al. Comparison of skin prick tests with specific immunoglobulin $\mathrm{E}$ in the diagnosis of fungal sensitization in patients with severe asthma. Clin Exp Allergy. 2009; 39:1677-83. [PubMed: 19689458]

29. Tschopp JM, Sistek D, Schindler C, et al. Current allergic asthma and rhinitis: diagnostic efficiency of three commonly used atopic markers (IgE, skin prick tests, and Phadiatop). Results from 8329 randomized adults from the SAPALDIA Study. Swiss Study on Air Pollution and Lung Diseases in Adults. Allergy. 1998; 53:608-13. [PubMed: 9689343]

30. Bacharier LB, Strunk RC, Mauger D, et al. Classifying asthma severity in children: mismatch between symptoms, medication use, and lung function. Am J Respir Crit Care Med. 2004; 170:426-32. [PubMed: 15172893]

31. Expert Panel Report 3 (EPR-3): guidelines for the diagnosis and management of asthma-summary report 2007. J Allergy Clin Immunol. 2007; 120(suppl):S94-138. [PubMed: 17983880]

32. van Dalen C, Harding E, Parkin J, et al. Suitability of forced expiratory volume in 1 second/forced vital capacity vs percentage of predicted forced expiratory volume in 1 second for the classification of asthma severity in adolescents. Arch Pediatr Adolesc Med. 2008; 162:1169-74. [PubMed: 19047545]

33. Sears MR, Greene JM, Willan AR, et al. A longitudinal, population-based, cohort study of childhood asthma followed to adulthood. N Engl J Med. 2003; 349:1414-22. [PubMed: 14534334]

34. Oswald H, Phelan PD, Lanigan A, et al. Childhood asthma and lung function in mid-adult life. Pediatr Pulmonol. 1997; 23:14-20. [PubMed: 9035194]

35. Covar RA, Spahn JD, Murphy JR, Szefler SJ, Childhood Asthma Management Program Research Group. Progression of asthma measured by lung function in the childhood asthma management program. Am J Respir Crit Care Med. 2004; 170:234-41. [PubMed: 15028558]

36. O’Byrne PM, Pedersen S, Lamm CJ, Tan WC, Busse WW, START Investigators Group. Severe exacerbations and decline in lung function in asthma. Am J Respir Crit Care Med. 2009; 179:1924. [PubMed: 18990678]

37. Awadh N, Muller NL, Park CS, et al. Airway wall thickness in patients with near fatal asthma and control groups: assessment with high resolution computed tomographic scanning. Thorax. 1998; 53:248-53. [PubMed: 9741365]

38. Paganin F, Seneterre E, Chanez P, et al. Computed tomography of the lungs in severe asthma: influence of disease severity and etiology. Am J Respir Crit Care Med. 1996; 153:110-14. [PubMed: 8542102]

39. Jensen SP, Lynch DA, Brown KK, Wenzel SE, Newell JD. High-resolution CT features of severe asthma and bronchiolitis obliterans. Clin Radiol. 2002; 57:1078-85. [PubMed: 12475532]

40. Kasahara K, Shiba K, Ozawa T, Okuda K, Adachi M. Correlation between the bronchial subepithelial layer and whole airway wall thickness in patients with asthma. Thorax. 2002; 57:242-46. [PubMed: 11867829]

41. Gupta S, Siddiqui S, Haldar P, et al. Qualitative analysis of high-resolution CT scans in severe asthma. Chest. 2009; 136:1521-28. [PubMed: 19542254]

42. Marchac V, Emond S, Mamou-Mani T, et al. Thoracic CT in pediatric patients with difficult-totreat asthma. Am J Roentgenol. 2002; 179:1245-52. [PubMed: 12388508] 
43. Saglani S, Papaioannou G, Khoo L, et al. Can HRCT be used as a marker of airway remodelling in children with difficult asthma? Respir Res. 2006; 7:46. [PubMed: 16566832]

44. de Blic J, Tillie-Leblond I, Emond S, et al. High-resolution computed tomography scan and airway remodeling in children with severe asthma. J Allergy Clin Immunol. 2005; 116:750-54. [PubMed: 16210046]

45. de Blic J, Scheinmann P. The use of imaging techniques for assessing severe childhood asthma. J Allergy Clin Immunol. 2007; 119:808-10. [PubMed: 17289134]

46. Pifferi M, Caransella D, Ragazzo V, Pietrobelli A, Boner AL. Low-density areas on highresolution computed tomograms in chronic pediatric asthma. J Pediatr. 2002; 141:104-08. [PubMed: 12091859]

47. Tillie-Leblond I, de Blic J, Jaubert F, Wallaert B, Scheinmann P, Gosset P. Airway remodeling is correlated with obstruction in children with severe asthma. Allergy. 2008; 63:533-41. [PubMed: 18394127]

48. Jain N, Covar RA, Gleason MC, Newell JD Jr, Gelfand EW, Spahn JD. Quantitative computed tomography detects peripheral airway disease in children. Pediatr Pulmonol. 2005; 40:211-18. [PubMed: 16015663]

49. Gustafsson PM. Peripheral airway involvement in CF and asthma compared by inert gas washout. Pediatr Pulmonol. 2007; 42:168-76. [PubMed: 17186546]

50. Gustafsson PM, De Jong PA, Tiddens HA, Lindblad A. Multiple-breath inert gas washout and spirometry versus structural lung disease in cystic fibrosis. Thorax. 2008; 63:129-34. [PubMed: 17675316]

51. Brouwer AF, Brand PL. Asthma education and monitoring: what has been shown to work. Pediatr Respir Rev. 2008; 9:193-200.

52. Warner JO. Review of prescribed treatment for children with asthma in 1990. BMJ. 1995; 311:663-66. [PubMed: 7549637]

53. Farber HJ, Chi FW, Capra A, et al. Use of asthma medication dispensing patterns to predict risk of adverse health outcomes: a study of Medicaid-insured children in managed care programs. Ann Allergy Asthma Immunol. 2004; 92:319-28. [PubMed: 15049395]

54. Bae YJ, Kim TB, Jee YK, et al. Severe asthma patients in Korea overestimate their adherence to inhaled corticosteroids. J Asthma. 2009; 46:591-95. [PubMed: 19657900]

55. Gamble J, Stevenson M, McClean E, Heaney LG. The prevalence of nonadherence in difficult asthma. Am J Respir Crit Care Med. 2009; 180:817-22. [PubMed: 19644048]

56. Bender B, Milgrom H, Rand C. Nonadherence in asthmatic patients: is there a solution to the problem? Ann Allergy Asthma Immunol. 1997; 79:177-85. [PubMed: 9305223]

57. Orrell-Valente JK, Jarlsberg LG, Hill LG, Cabana MD. At what age do children start taking asthma medicines on their own? Pediatrics. 2008; 122:e1186-92. [PubMed: 19047221]

58. Kamps AW, van Ewijk B, Roorda RJ, Brand PL. Poor inhalation technique, even after inhalation instructions, in children with asthma. Pediatr Pulmonol. 2000; 29:39-42. [PubMed: 10613785]

59. Kamps AW, Brand PL, Roorda RJ. Determinants of correct inhalation technique in children attending a hospital-based asthma clinic. Acta Paediatr. 2002; 91:159-63. [PubMed: 11952002]

60. Walia M, Paul L, Satyavani A, Lodha R, Kalaivani M, Kabra SK. Assessment of inhalation technique and determinants of incorrect performance among children with asthma. Pediatr Pulmonol. 2006; 41:1082-87. [PubMed: 16989001]

61. Chalmers GW, Macleod KJ, Little SA, Thomson LJ, McSharry CP, Thomson NC. Influence of cigarette smoking on inhaled corticosteroid treatment in mild asthma. Thorax. 2002; 57:226-30. [PubMed: 11867826]

62. Chaudhuri R, Livingston E, McMahon AD, Thomson L, Borland W, Thomson NC. Cigarette smoking impairs the therapeutic response to oral corticosteroids in chronic asthma. Am J Respir Crit Care Med. 2003; 168:1308-11. [PubMed: 12893649]

63. Tomlinson JE, McMahon AD, Chaudhuri R, Thompson JM, Wood SF, Thomson NC. Efficacy of low and high dose inhaled corticosteroid in smokers versus non-smokers with mild asthma. Thorax. 2005; 60:282-87. [PubMed: 15790982] 
64. Livingston E, Chaudhuri R, McMahon AD, Fraser I, McSharry CP, Thomson NC. Systemic sensitivity to corticosteroids in smokers with asthma. Eur Respir J. 2007; 29:64-71. [PubMed: 16899479]

65. Ranganathan SC, Payne DN, Jaffe A, McKenzie SA. Difficult asthma: defining the problems. Pediatr Pulmonol. 2001; 31:114-20. [PubMed: 11180686]

66. Teach SJ, Crain EF, Quint DM, Hylan ML, Joseph JG. Indoor environmental exposures among children with asthma seen in an urban emergency department. Pediatrics. 2006; 117:S152-58. [PubMed: 16777831]

67. De Boeck K, Moens M, Van Der Aa N, et al. 'Difficult asthma': can symptoms be controlled in a structured environment? Pediatr Pulmonol. 2009; 44:743-48. [PubMed: 19598272]

68. Yang SR, Chida AS, Bauter MR, et al. Cigarette smoke induces proinflammatory cytokine release by activation of NF-kappaB and posttranslational modifications of histone deacetylase in macrophages. Am J Physiol Lung Cell Mol Physiol. 2006; 291:L46-57. [PubMed: 16473865]

69. Sulakvelidze I, Inman MD, Rerecich T, O'Byrne PM. Increases in airway eosinophils and interleukin-5 with minimal bronchoconstriction during repeated low-dose allergen challenge in atopic asthmatics. Eur Respir J. 1998; 11:821-27. [PubMed: 9623683]

70. Kam JC, Szefler SJ, Surs W, Sher ER, Leung DY. Combination IL-2 and IL-4 reduces glucocorticoid receptor-binding affinity and T cell response to glucocorticoids. J Immunol. 1993; 151:3460-66. [PubMed: 8376786]

71. Nimmagadda SR, Szefler SJ, Spahn JD, Surs W, Leung DYM. Allergen exposure decreases glucocorticoid receptor binding affinity and steroid responsiveness in atopic asthmatics. Am Rev Respir Crit Care Med. 1997; 155:87-93.

72. Murray CS, Poletti G, Kebadze T, et al. Study of modifiable risk factors for asthma exacerbations: virus infection and allergen exposure increase the risk of asthma hospital admissions in children. Thorax. 2006; 61:376-82. [PubMed: 16384881]

73. Almqvist C, Wickman M, Perfetti L, et al. Worsening of asthma in children allergic to cats, after indirect exposure to cat at school. Am J Respir Crit Care Med. 2001; 163:694-98. [PubMed: 11254526]

74. Sheikh A, Hurwitz B, Shehata Y. House dust mite avoidance measures for perennial allergic rhinitis. Cochrane Database Syst Rev. 2007; 1:CD001563. [PubMed: 17253461]

75. Dust-mite control measures of no use. Lancet. 2008; 371:1390.

76. Platts-Mills TA. Allergen avoidance in the treatment of asthma: problems with the meta-analyses. J Allergy Clin Immunol. 2008; 122:694-96. [PubMed: 19014759]

77. Ingram J, Sporik R, Rose G, Honsinger R, Chapman M, Platts-Mills TA. Quantitative assessment of exposure to $\operatorname{dog}(\mathrm{Can} \mathrm{f} \mathrm{1)}$ and cat (Fel d 1) allergens: relationship to sensitization and asthma among children living in Los Alamos, New Mexico. J Allergy Clin Immunol. 1995; 96:449-56. [PubMed: 7560654]

78. Gruchalla RS, Pongracic J, Plaut M, et al. Inner City Asthma Study: relationships among sensitivity, allergen exposure, and asthma morbidity. J Allergy Clin Immunol. 2005; 115:478-85. [PubMed: 15753892]

79. Lindfors A, van Hage-Hamsten M, Rietz H, Wickman M, Nordvall SL. Influence of interaction of environmental risk factors and sensitization in young asthmatic children. J Allergy Clin Immunol. 1999; 104:755-62. [PubMed: 10518818]

80. Strachan DP, Carey IM. Home environment and severe asthma in adolescence: a population based case-control study. BMJ. 1995; 311:1053-56. [PubMed: 7580660]

81. Cullinan P, MacNeill SJ, Harris JM, et al. Early allergen exposure, skin prick responses, and atopic wheeze at age 5 in English children: a cohort study. Thorax. 2004; 59:855-61. [PubMed: 15454651]

82. Langley SJ, Goldthorpe S, Craven M, Woodcock A, Custovic A. Relationship between exposure to domestic allergens and bronchial hyperresponsiveness in non-sensitised, atopic asthmatic subjects. Thorax. 2005; 60:17-21. [PubMed: 15618577]

83. Chinn S, Heinrich J, Antó JM, et al. Bronchial responsiveness in atopic adults increases with exposure to cat allergen. Am J Respir Crit Care Med. 2007; 176:20-26. [PubMed: 17446334] 
84. Sandberg S, Paton JY, Ahola S, et al. The role of acute and chronic stress in asthma attacks in children. Lancet. 2000; 356:982-87. [PubMed: 11041399]

85. Sandberg S, McCann DC, Ahola S, Oja H, Paton JY, McGuinness D. Positive experiences and the relationship between stress and asthma in children. Acta Paediatr. 2002; 91:152-58. [PubMed: 11952001]

86. Sandberg S, Järvenpää S, Penttinen A, Paton JY, McCann DC. Asthma exacerbations in children immediately following stressful life events: a Cox's hierarchical regression. Thorax. 2004; 59:1046-51. [PubMed: 15563703]

87. Liu LY, Coe CL, Swenson CA, Kelly EA, Kita H, Busse WW. School examinations enhance airway inflammation to antigen challenge. Am J Respir Crit Care Med. 2002; 165:1062-67. [PubMed: 11956045]

88. Havemann BD, Henderson CA, El-Serag HB. The association between gastro-oesophageal reflux disease and asthma: a systematic review. Gut. 2007; 56:1654-64. [PubMed: 17682001]

89. Thakkar K, Boatright RO, Gilger MA, El-Serag HB. Gastroesophageal reflux and asthma in children: a systematic review. Pediatrics. 2010; 125:e925-30. [PubMed: 20351005]

90. Sundberg R, Torén K, Höglund D, Aberg N, Brisman J. Nasal symptoms are associated with school performance in adolescents. J Adolesc Health. 2007; 40:581-83. [PubMed: 17531771]

91. Bousquet J, Bachert C, Canonica GW, et al. Extended Global Allergy and Asthma European Network, World Allergy Organization and Allergic Rhinitis and its Impact on Asthma Study Group. Unmet needs in severe chronic upper airway disease (SCUAD). J Allergy Clin Immunol. 2009; 124:428-33. [PubMed: 19660803]

92. Rollin M, Seymour K, Hariri M, Harcourt J. Rhinosinusitis, symptomatology \& absence of polyposis in children with primary ciliary dyskinesia. Rhinology. 2009; 47:75-78. [PubMed: 19382500]

93. Abu-Hassan M, Tannous B, Weinberger M. Exercise induced dyspnea in children and adolescents: if not asthma then what? Ann Allergy Asthma Immunol. 2005; 94:366-71. [PubMed: 15801248]

94. Seear M, Wensley D, West N. How accurate is the diagnosis of exercise-induced asthma among Vancouver schoolchildren? Arch Dis Child. 2005; 90:898-902. [PubMed: 15855180]

95. Van Dixhoorn DJ, Duivendorm HJ. Efficacy of Nijmegen questionnaire in recognition of the hyperventilation syndrome. J Psychosom Res. 1985; 29:199-206. [PubMed: 4009520]

96. Male I, Richter H, Seddon P. Children's perception of breathlessness in acute asthma. Arch Dis Child. 2000; 83:325-29. [PubMed: 10999869]

97. Bijl-Hofland ID, Cloosterman SG, Folgering HT, Akkermans RP, van Schayck CP. Relation of the perception of airway obstruction to the severity of asthma. Thorax. 1999; 54:15-19. [PubMed: 10343625]

98. Sutherland ER, Goleva E, Strand M, Beuther DA, Leung DY. Body mass and glucocorticoid response in asthma. Am J Respir Crit Care Med. 2008; 178:682-87. [PubMed: 18635892]

99. Roberts G, Patel N, Levi-Schaffer F, Habibi P, Lack G. Food allergy as a risk factor for lifethreatening asthma in childhood: a case-controlled study. J Allergy Clin Immunol. 2003; 112:16874. [PubMed: 12847494]

100. Simpson AB, Glutting J, Yousef E. Food allergy and asthma morbidity in children. Pediatr Pulmonol. 2007; 42:489-95. [PubMed: 17469157]

101. Evans R 3rd, Gergen PJ, Mitchell H, et al. A randomized clinical trial to reduce asthma morbidity among inner-city children: results of the National Cooperative Inner-City Asthma Study. J Pediatr. 1999; 135:332-38. [PubMed: 10484799]

102. Morgan WJ, Crain EF, Gruchalla RS, et al. Inner-City Asthma Study Group. Results of a homebased environmental intervention among urban children with asthma. N Engl J Med. 2004; 351:1068-80. [PubMed: 15356304]

103. Kattan M, Stearns SC, Crain EF, et al. Cost-effectiveness of a home-based environmental intervention for inner-city children with asthma. J Allergy Clin Immunol. 2005; 116:1058-63. [PubMed: 16275376]

104. Smith JR, Mugford M, Holland R, et al. A systematic review to examine the impact of psychoeducational interventions on health outcomes and costs in adults and children with difficult asthma. Int Soc Technol Assess Health Care Meet. 2005; 19:172. 
105. Kotses H, Stout C, Wigal JK. Individualised asthma self-management: a beginning. J Asthma. 1991; 28:287-89. [PubMed: 1890082]

106. Kotses H, Stout C, McConnaughty K, Winder JA, Creer TL. Evaluation of individualized asthma self-management programs. J Asthma. 1996; 33:113-18. [PubMed: 8609098]

107. Payne DN, Hubbard M, McKenzie SA. Corticosteroid unresponsiveness in asthma: primary or acquired? Pediatr Pulmonol. 1998; 25:59-61. [PubMed: 9475332]

108. Sher ER, Leung DYM, Surs W, et al. Steroid-resistant asthma. Cellular mechanisms contributing to inadequate response to glucocorticoid therapy. J Clin Invest. 1994; 93:33-39. [PubMed: 8282803]

109. Adcock IM, Barnes PJ. Molecular mechanisms of corticosteroid resistance. Chest. 2008; 134:394-401. [PubMed: 18682458]

110. Payne DNR, Adcock IM, Wilson NM, Oates T, Scallan M, Bush A. Relationship between exhaled nitric oxide and mucosal eosinophilic inflammation in children with difficult asthma, after treatment with oral prednisolone. Am J Respir Crit Care Med. 2001; 164:1376-81. [PubMed: 11704581]

111. Jenkins HA, Cool C, Szefler SJ, Covar R, Brugman S, Gelfand EW, Spahn JD. Histopathology of severe childhood asthma. A case series. Chest. 2003; 124:32-41. [PubMed: 12853499]

112. Ito K, Chung KF, Adcock IM. Update on glucocorticoid action and resistance. J Allergy Clin Immunol. 2006; 117:522-43. [PubMed: 16522450]

113. Schatz M, Sorkness CA, Li JT, et al. Asthma Control Test: reliability, validity, and responsiveness in patients not previously followed by asthma specialists. J Allergy Clin Immunol. 2006; 117:549-56. [PubMed: 16522452]

114. Warke TJ, Fitch PS, Brown V, et al. Exhaled nitric oxide correlates with airway eosinophils in childhood asthma. Thorax. 2002; 57:383-87. [PubMed: 11978911]

115. Cai Y, Carty K, Henry RL, Gibson PG. Persistence of sputum eosinophilia in children with controlled asthma when compared with healthy children. Eur Respir J. 1998; 11:848-53. [PubMed: 9623687]

116. Lex C, Payne DN, Zacharasiewicz A, et al. Is a two-week trial of oral prednisolone predictive of target lung function in pediatric asthma? Pediatr Pulmonol. 2005; 39:521-27. [PubMed: 15765544]

117. Bossley C, Saglani S, Fleming L, et al. Noninvasive markers of inflammation as a measurement of corticosteroid responsiveness in children with severe asthma (sa). Eur Respir J. 2009; 34(suppl 53):566S.

118. Adams NP, Bestall JC, Jones P, Lasserson TJ, Griffiths B, Cates CJ. Fluticasone at different doses for chronic asthma in adults and children. Cochrane Database Syst Rev. 2008; 4:CD003534. [PubMed: 18843646]

119. Pauwels RA, Löfdahl CG, Postma DS, et al. Formoterol and Corticosteroids Establishing Therapy (FACET) International Study Group. Effect of inhaled formoterol and budesonide on exacerbations of asthma. N Engl J Med. 1997; 337:1405-11. [PubMed: 9358137]

120. Bisgaard H, Le Roux P, Bjåmer D, Dymek A, Vermeulen JH, Hultquist C. Budesonide/ formoterol maintenance plus reliever therapy: a new strategy in pediatric asthma. Chest. 2006; 130:1733-43. [PubMed: 17166990]

121. Cates CJ, Lasserson TJ. Combination formoterol and inhaled steroid versus beta2-agonist as relief medication for chronic asthma in adults and children. Cochrane Database Syst Rev. 2009; 2:CD007085. [PubMed: 19160317]

122. Panickar JR, Kenia P, Silverman M, Grigg J. Intramuscular triamcinolone for difficult asthma. Pediatr Pulmonol. 2005; 39:421-25. [PubMed: 15666368]

123. Humbert M, Beasley R, Ayres J, et al. Benefits of omalizumab as add-on therapy in patients with severe persistent asthma who are inadequately controlled despite best available therapy (GINA 2002 step 4 treatment): INNOVATE. Allergy. 2005; 60:309-16. [PubMed: 15679715]

124. Massanari M, Milgrom H, Pollard S, et al. Adding omalizumab to the therapy of adolescents with persistent uncontrolled moderate—severe allergic asthma. Clin Pediatr. 2009; 48:859-65. 
125. Lanier B, Bridges T, Kulus M, Taylor AF, Berhane I, Vidaurre CF. Omalizumab for the treatment of exacerbations in children with inadequately controlled allergic (IgE-mediated) asthma. J Allergy Clin Immunol. 2009; 124:1210-16. [PubMed: 19910033]

126. Coren ME, Rosenthal M, Bush A. The use of cyclosporin in corticosteroid dependent asthma. Arch Dis Child. 1997; 77:522-23. [PubMed: 9496189]

127. Bernstein IL, Bernstein DI, Dubb JW, Faiferman I, Wallin B. A placebo-controlled multi-center study of auranofin in the treatment of patients with corticosteroid-dependent asthma. Auranofin Multicenter Drug Trial. J Allergy Clin Immunol. 1996; 98:317-24. [PubMed: 8757209]

128. Sole D, Costa-Carvalho BT, Soares FJ, Rullo VV, Naspitz CK. Methotrexate in the treatment of corticodependent asthmatic children asthmatic children. J Invest Allergol Clin Immunol. 1996; 6:126-30.

129. Haselkorn T, Zeiger RS, Chipps BE, et al. Recent asthma exacerbations predict future exacerbations in children with severe or difficult-to-treat asthma. J Allergy Clin Immunol. 2009; 124:921-27. [PubMed: 19895984]

130. Dougherty RH, Fahy JV. Acute exacerbations of asthma: epidemiology, biology and the exacerbation-prone phenotype. Clin Exp Allergy. 2009; 39:193-202. [PubMed: 19187331]

131. Contoli M, Message SD, Laza-Stanca V, et al. Role of deficient type III interferon-lambda production in asthma exacerbations. Nat Med. 2006; 12:1023-26. [PubMed: 16906156]

132. Khaitov MR, Laza-Stanca V, Edwards MR, et al. Respiratory virus induction of alpha-, beta- and lambda-interferons in bronchial epithelial cells and peripheral blood mononuclear cells. Allergy. 2009; 64:375-86. [PubMed: 19175599]

133. Haselkorn T, Fish JE, Zeiger RS, et al. TENOR Study Group. Consistently very poorly controlled asthma, as defined by the impairment domain of the Expert Panel Report 3 guidelines, increases risk for future severe asthma exacerbations in The Epidemiology and Natural History of Asthma: Outcomes and Treatment Regimens (TENOR) study. J Allergy Clin Immunol. 2009; 124:895902. e1-4. [PubMed: 19811812]

134. Miller MK, Lee JH, Miller DP, Wenzel SE, TENOR Study Group. Recent asthma exacerbations: a key predictor of future exacerbations. Respir Med. 2007; 101:481-89. [PubMed: 16914299]

135. Belessis Y, Dixon S, Thomsen A, et al. Risk factors for an intensive care unit admission in children with asthma. Pediatr Pulmonol. 2004; 37:201-09. [PubMed: 14966813]

136. Sur S, Crotty TB, Kephart GM, et al. Sudden-onset fatal asthma. A distinct entity with few eosinophils and relatively more neutrophils in the airway submucosa? Am Rev Respir Dis. 1993; 148:713-19. [PubMed: 8368644]

137. Carroll NE, Carello S, Cooke C, James A. Airway structure and inflammatory cells in fatal attacks of asthma. Eur Respir J. 1996; 9:709-15. [PubMed: 8726935]

138. Gibson PG, Norzila MZ, Fakes K, Simpson J, Henry RL. Pattern of airway inflammation and its determinants in children with acute severe asthma. Pediatr Pulmonol. 1999; 28:261-70. [PubMed: 10497375]

139. Marks GB, Colquhoun JR, Girgis ST, et al. Thunderstorm outflows preceding epidemics of asthma during spring and summer. Thorax. 2001; 56:468-71. [PubMed: 11359963]

140. Ballester F, Soriano JB, Otero I, et al. Asthma visits to emergency rooms and soybean unloading in the harbors of Valencia and A Coruña, Spain. Am J Epidemiol. 1999; 149:315-22. [PubMed: 10025473]

141. Wark PA, Simpson J, Hensley MJ, Gibson PG. Airway inflammation in thunderstorm asthma. Clin Exp Allergy. 2002; 32:1750-56. [PubMed: 12653167]

142. Haldar P, Brightling CE, Hargadon B, et al. Mepolizumab and exacerbations of refractory eosinophilic asthma. N Engl J Med. 2009; 360:973-84. [PubMed: 19264686]

143. Nair P, Pizzichini MM, Kjarsgaard M, et al. Mepolizumab for prednisone-dependent asthma with sputum eosinophilia. N Engl J Med. 2009; 360:985-93. [PubMed: 19264687]

144. McKean M, Ducharme F. Inhaled steroids for episodic viral wheeze of childhood. Cochrane Database Syst Rev. 2000; 2:CD001107. [PubMed: 10796596]

145. Robertson CF, Price D, Henry R, et al. Short-course montelukast for intermittent asthma in children: a randomized controlled trial. Am J Respir Crit Care Med. 2007; 175:323-29.

[PubMed: 17110643] 
146. Payne DNR, Balfour-Lynn IM, Biggart EA, Bush A, Rosenthal M. Subcutaneous terbutaline in children with chronic severe asthma. Pediatr Pulmonol. 2002; 33:356-61. [PubMed: 11948980]

147. Drazen JM, O'Byrne PM. Risks of long-acting beta-agonists in achieving asthma control. N Engl J Med. 2009; 360:1671-72. [PubMed: 19369675]

148. Weatherall M, Wijesinghe M, Perrin K, Harwood M, Beasley R. Meta-analysis of the risk of mortality with salmeterol and the effect of concomitant inhaled corticosteroid therapy. Thorax. 2010; 65:39-43. [PubMed: 20029037]

149. Lex C, Payne DN, Zacharasiewicz A, et al. Sputum induction in children with difficult asthma: safety, feasibility, and inflammatory cell profiles. Pediatr Pulmonol. 2005; 39:318-24. [PubMed: 15678506]

150. Yasui K, Agematsu K, Shinozaki K, et al. Theophylline induces neutrophil apoptosis through adenosine A2A receptor antagonism. J Leukoc Biol. 2000; 67:529-35. [PubMed: 10770286]

151. Wolter J, Seeney S, Bell S, et al. Effect of long term treatment with azithromycin on disease parameters in cystic fibrosis: a randomised controlled trial. Thorax. 2002; 57:212-16. [PubMed: 11867823]

152. Equi A, Balfour-Lynn I, Bush A, Rosenthal M. Long term azithromycin in children with cystic fibrosis: a randomized, placebo-controlled crossover trial. Lancet. 2002; 360:978-84. [PubMed: 12383667]

153. Saiman L, Marshall BC, Meyer-Hamblett N, et al. Azithromycin in patients with cystic fibrosis chronically infected with Pseudomonas aeruginosa: a randomized controlled trial. JAMA. 2003; 290:1749-56. [PubMed: 14519709]

154. Clement A, Tamalet A, Leroux E, Ravilly S, Fauroux B, Jais JP. Long term effects of azithromycin in patients with cystic fibrosis: a double blind, placebo controlled trial. Thorax. 2006; 61:895-902. [PubMed: 16809416]

155. Kudoh S, Azuma A, Yamamoto M, Izumi T, Ando M. Improvement of survival in patients with diffuse panbronchiolitis treated with low-dose erythromycin. Am J Respir Crit Care Med. 1998; 157:1829-32. [PubMed: 9620913]

156. Anwar GA, Bourke SC, Afolabi G, Middleton P, Ward C, Rutherford RM. Effects of long-term low-dose azithromycin in patients with non-CF bronchiectasis. Respir Med. 2008; 102:1494-96. [PubMed: 18653323]

157. Simpson JL, Powell H, Boyle MJ, Scott RJ, Gibson PG. Clarithromycin targets neutrophilic airway inflammation in refractory asthma. Am J Respir Crit Care Med. 2008; 177:148-55. [PubMed: 17947611]

158. Amayasu H, Yoshida S, Ebana S, et al. Clarithromycin suppresses bronchial hyperresponsiveness associated with eosinophilic inflammation in patients with asthma. Ann Allergy Asthma Immunol. 2000; 84:594-98. [PubMed: 10875487]

159. Meagher LC, Cousin JM, Seckl JR, Haslett C. Opposing effects of glucocorticoids on the rate of apoptosis in neutrophilic and eosinophilic granulocytes. J Immunol. 1996; 156:4422-28. [PubMed: 8666816]

160. O'Hallaren MT, Yunginger JW, Offord KP, et al. Exposure to aeroallergen as a possible precipitating factor in respiratory arrest in young patients with asthma. N Engl J Med. 1991; 324:359-63. [PubMed: 1987459]

161. Neukirch C, Henry C, Leynaert B, Liard R, Bousquet J, Neukirch F. Is sensitization to Alernaria alternata a risk factor for severe asthma? A population based study. J Allergy Clin Immunol. 1999; 103:709-11. [PubMed: 10200024]

162. Black PN, Udy AA, Brodie SM. Sensitivity to fungal allergens is a risk factor for life-threatening asthma. Allergy. 2000; 55:501-04. [PubMed: 10843433]

163. Vicencio AG, Muzumdar H, Tsirilakis K, Kessel A, Nandalike K, Goldman DL. Severe asthma with fungal sensitization in a child: response to itraconazole therapy. Pediatrics. 2010; 125:e1255-58. [PubMed: 20385639]

164. De Wachter E, Vanbesien J, De Schutter I, Malfroot A, De Schepper J. Rapidly developing Cushing syndrome in a 4-year-old patient during combined treatment with itraconazole and inhaled budesonide. Eur J Pediatr. 2003; 162:488-89. [PubMed: 12719971] 
165. Castro M, Rubin AS, Laviolette M, et al. AIR2 Trial Study Group. Effectiveness and safety of bronchial thermoplasty in the treatment of severe asthma: a multicenter, randomized, doubleblind, sham-controlled clinical trial. Am J Respir Crit Care Med. 2010; 181:116-24. [PubMed: 19815809]

166. Corren J, Busse W, Meltzer EO, et al. A randomized, controlled, phase 2 study of AMG 317, an IL-4Ralpha antagonist, in patients with asthma. Am J Respir Crit Care Med. 2010; 181:788-96. [PubMed: 20056900]

167. Milanese M, Crimi E, Scordamaglia A, Riccio A, et al. On the functional consequences of bronchial basement membrane thickening. J Appl Physiol. 2001; 91:1035-40. [PubMed: 11509495]

168. Fujitani Y, Trifilieff A. In vivo and in vitro effects of SAR 943, a rapamycin analogue, on airway inflammation and remodeling. Am J Respir Crit Care Med. 2003; 167:193-98. [PubMed: 12406821]

169. Brand PL, Roorda RJ. Usefulness of monitoring lung function in asthma. Arch Dis Child. 2003; 88:1021-25. [PubMed: 14612375]

170. Zacharasiewicz A, Wilson N, Lex C, et al. Clinical use of non-invasive measurements of airway inflammation in steroid reduction in children. Am J Respir Crit Care Med. 2005; 177:1077-82. [PubMed: 15709050]

171. Pijnenburg MW, Hofhuis W, Hop WC, De Jongste JC. Exhaled nitric oxide predicts asthma relapse in children with clinical asthma remission. Thorax. 2005; 60:215-18. [PubMed: 15741438]

172. Pijnenburg MW, Bakker EM, Hop WC, De Jongste JC. Titrating steroids on exhaled nitric oxide in children with asthma: a randomized controlled trial. Am J Respir Crit Care Med. 2005; 172:831-36. [PubMed: 15976380]

173. Fleming L, Wilson N, Regamey N, Bush A. The use of non-invasive markers of inflammation to guide management in children with severe asthma. Am J Respir Crit Care Med. 2009; 179(suppl):A1305.

174. Fleming L, Wilson N, Regamey N, Bush A. Are inflammatory phenotypes in children with severe asthma stable? Eur Respir J. 2007; 30(suppl 51):483S.

175. Fleming L, Tsartsali L, Wilson N, Regamey N, Bossley C, Bush A. Discordance between sputum eosinophils and exhaled nitric oxide in children with asthma. Thorax. 2008; 63(suppl V11):A34.

176. Green RH, Brightling CE, McKenna S, et al. Asthma exacerbations and sputum eosinophil counts: a randomised controlled trial. Lancet. 2002; 360:1715-21. [PubMed: 12480423]

177. Petsky HL, Cates CJ, Li A, Kynaston JA, Turner C, Chang AB. Tailored interventions based on exhaled nitric oxide versus clinical symptoms for asthma in children and adults. Cochrane Database Syst Rev. 2009; 4:CD006340. [PubMed: 19821360]

178. Lex C, Ferreira F, Zacharasiewicz A, et al. Airway eosinophilia in children with severe asthma: predictive values of non-invasive tests. Am J Respir Crit Care Med. 2006; 174:1286-91. [PubMed: 16973985]

179. Kraft M, Djukanovic R, Wilson S, Holgate ST, Martin RJ. Alveolar tissue inflammation in asthma. Am J Respir Crit Care Med. 1996; 154:1505-10. [PubMed: 8912772]

180. Sutherland ER, Martin RJ, Bowler RP, Zhang Y, Rex MD, Kraft M. Physiologic correlates of distal lung inflammation in asthma. J Allergy Clin Immunol. 2004; 113:1046-50. [PubMed: 15208583]

181. Kraft M, Martin RJ, Wilson S, Djukanovic R, Holgate ST. Lymphocyte and eosinophil influx into alveolar tissue in nocturnal asthma. Am J Respir Crit Care Med. 1999; 159:228-34. [PubMed: 9872843]

182. Tsoukias NM, George SC. A two-compartment model of pulmonary nitric oxide exchange dynamics. J Appl Physiol. 1998; 85:653-66. [PubMed: 9688744]

183. Tsoukias NM, Shin HW, Wilson AF, George SC. A single-breath technique with variable flow rate to characterize nitric oxide exchange dynamics in the lungs. J Appl Physiol. 2001; 91:47787. [PubMed: 11408466] 
184. Paraskakis E, Brindicci C, Fleming L, et al. Measurement of bronchial and alveolar nitric oxide production in normal children and children with asthma. Am J Respir Crit Care Med. 2006; 174:260-67. [PubMed: 16627868]

185. Cohen J, Douma WR, ten Hacken NH, Vonk JM, Oudkerk M, Postma DS. Ciclesonide improves measures of small airway involvement in asthma. Eur Respir J. 2008; 31:1213-20. [PubMed: 18287130] 


\section{Search strategy and selection criteria}

We identified references for this Review by searches of PubMed with the following search terms "severe asthma" or "therapy-resistant asthma" or "difficult asthma" from 1995 to June, 2010. Only papers published in English were included. Articles were chosen on the basis of their relevance to the paper and we also searched their bibliographies for references. We also included articles from our personal archives. 


\section{Panel 1:Domains of asthma severity in children}

1. Level of current prescribed treatment

2. Level of current baseline control of asthma over at least the preceding month (note there is no evidence for the definition of this time period)

3. Immediate past burden of asthma exacerbations, including number and severity (possibly over past 6 months, again there is no evidence for this definition)

4. Future risk of complications, including: risk of failure of normal postnatal airway growth; risk of future loss of asthma control; risk of future exacerbations; risk of phenotype change from episodic, viral, to multi-trigger ${ }^{11}$ (mainly in pre-school children); and risk of harm from drugs 


\section{Panel 2: The different problems that trigger referral}

- Persistent (most days, for at least 3 months) chronic symptoms (which prompt use of short-acting $\beta 2$ agonists three times per week or more) of airway obstruction despite high-dose inhaled corticosteroid (beclometasone equivalent $800 \mu \mathrm{g}$ per day) and trials of add-on drugs (long-acting $\beta 2$ agonists, leukotriene receptor antagonists, and oral theophylline in a low, anti-inflammatory dose). The inhaled corticosteroid threshold is arbitrary. Although the plateau of the inhaled corticosteroid dose-response curve is low for mild asthma (perhaps even $200 \mu \mathrm{g}$ per day 2), it might be higher in patients with steroid resistance. ${ }^{15}$ There is a poor correlation between symptoms and parental administration of $\beta 2$ agonists. ${ }^{16}$

- Type 1 brittle asthma ${ }^{17}$ (chaotic swings in peak flow in most days over a period of months). There are insufficient paediatric data to give a more precise definition of this form of asthma; nearly all data are from studies in adults.

- Recurrent severe asthma exacerbations that have required at least one admission to an intensive care unit, at least two hospital admissions with intravenous treatment, or two or more courses of oral steroids during the past year despite therapy as described above for persistent chronic symptoms.

- Type 2 brittle asthma ${ }^{17}$ (sudden and catastrophic attack after apparently good control); again, most data come from adults.

- Persistent airflow limitation: after oral steroid, the post-bronchodilator $Z$ score is less than -1.96 for forced expired volume in $1 \mathrm{~s}\left(\mathrm{FEV}_{1}\right)$ with appropriate reference populations. ${ }^{18}$

- The necessity of prescription of oral steroids daily or every other day. 
Table 1

Possible criteria for steroid responsiveness in children with severe asthma

\begin{tabular}{ll}
\hline & Requirement \\
\hline Symptom response & $\begin{array}{l}\text { Asthma control test }{ }^{113} \text { rises to a score of } \geq 20 / 25, \text { or by at least } \\
5 \text { points }\end{array}$ \\
& $\begin{array}{l}\mathrm{FEV}_{1} \text { rises to normal }(\geq-1.96 \text { Z-score }) \text { or by } \geq 15 \% \\
\text { No residual bronchodilator response }\end{array}$ \\
$\begin{array}{l}\text { Lung function response } \\
\text { Inflammatory response (if paired } \\
\text { induced sputum samples available) }\end{array}$ & Sputum eosinophil count normal $(\preceq .5 \%)^{114}$ \\
$\begin{array}{l}\text { Inflammatory response (if paired } \\
\text { induced sputum samples not available) }\end{array}$ & Fractional exhaled nitric oxide ${ }^{*}$ normal $\left(<24\right.$ parts per billion) ${ }^{115}$ \\
\hline
\end{tabular}

Non-response is classified as no improvement in any domain; partial response is improvement in one or two domains; and complete response is normalisation in all three domains.

Exhaled nitric oxide measured at flow $50 \mathrm{~mL} / \mathrm{s} . \mathrm{FEV}_{1}=$ forced expired volume in $1 \mathrm{~s}$. 
Table 2

Summary of management options by presenting problem, after a full multidisciplinary assessment

\begin{tabular}{|c|c|}
\hline & Treatment \\
\hline Persistent chronic symptoms & $\begin{array}{l}\text { High-dose inhaled corticosteroids; SMART regimen; trial of low-dose oral } \\
\text { corticosteroids (preferably every other day); omalizumab if meets criteria (see text); } \\
\text { steroid-sparing drug (methotrexate, azathioprine, ciclosporin) }\end{array}$ \\
\hline $\begin{array}{l}\text { Type } 1 \text { brittle asthma (chronic chaotic variation in } \\
\text { peak flow) }\end{array}$ & $\begin{array}{l}\text { Ensure no residual airway inflammation when well; appropriate dose of inhaled } \\
\text { corticosteroids plus either high-dose long-acting } \beta 2 \text { agonist (formoterol) or consider a } \\
\text { double-blind trial of continuous subcutaneous terbutaline }\end{array}$ \\
\hline Recurrent severe exacerbations & $\begin{array}{l}\text { Ensure no residual airway inflammation when well (appropriate dose of inhaled } \\
\text { corticosteroids); ensure allergen exposure minimised; consider either or both of high- } \\
\text { dose inhaled corticosteroids or leukotriene receptor antagonists with exacerbations }\end{array}$ \\
\hline $\begin{array}{l}\text { Type } 2 \text { brittle asthma (sudden acute catastrophic } \\
\text { deterioration on the background of apparently } \\
\text { previously good asthma control) }\end{array}$ & $\begin{array}{l}\text { Ensure no residual airway inflammation when well (inhaled corticosteroids); provide } \\
\text { injectable epinephrine for emergencies }\end{array}$ \\
\hline Persistent airflow obstruction & $\begin{array}{l}\text { Reduce treatment to minimum; if obliterative bronchiolitis is the cause, treatment can } \\
\text { often be stopped altogether }\end{array}$ \\
\hline Prescription of oral steroids daily or every other day & $\begin{array}{l}\text { Omalizumab if meets criteria (see text); steroid-sparing drug (methotrexate, } \\
\text { azathioprine, ciclosporin) }\end{array}$ \\
\hline
\end{tabular}

SMART=Symbicort maintenance and reliever. 
Table 3

Treatment of particular forms of severe therapy-resistant asthma, after a full multidisciplinary assessment

\begin{tabular}{ll}
\hline & Treatment strategy \\
\hline $\begin{array}{l}\text { Pauci-cellular airway cytology with } \\
\text { persistent symptoms }\end{array}$ & $\begin{array}{l}\text { Reduce dose of inhaled corticosteroids; consider SMART regimen or subcutaneous terbutaline with } \\
\text { continued inhaled corticosteroids }\end{array}$ \\
Neutrophilic cytology & $\begin{array}{l}\text { Re-consider the diagnosis: other causes of airway neutrophilia (gastro-oesophageal reflux, cystic } \\
\text { fibrosis); low-dose oral theophyllines to accelerate neutrophil apoptosis; oral macrolides; consider } \\
\text { inhaled steroid taper with caution }\end{array}$ \\
Severe asthma with fungal sensitisation & Look for environmental exposures (including nebulisers); oral itraconazole or voriconazole \\
\hline
\end{tabular}

SMART $=$ Symbicort maintenance and reliever. 